\title{
Randomized controlled trial of herbal extracts (Eugenia polyantha, Apium graveolens, Nigella sativa) and allopurinol effect on serum uric acid, urinary uric acid and high sensitivity C-reactive protein levels in subject with hyperuricemia
}

Bantar Suntoko ${ }^{1}$, Rakhma Yanti Hellmi ${ }^{1}$,Ika Vemilia W ${ }^{1}$, Stepanus Agung L ${ }^{1}$

${ }^{1}$ Division of Rheumatology in the Internal Medicine Department, Diponegoro University-Dr. Kariadi hospital

\section{A R T I C L E I N F O \\ Keywords: \\ Lupus Low Disease Activity Atherosclerotic Plaque \\ Carotid Artery}

\section{Corresponding author:}

E-mail address: hamijoyo@yahoo.com

All authors have reviewed and approved the final version of the manuscript.

https://doi.org/10.37275/IJR.v11i2.129

\begin{abstract}
A B S T R A C T
Background Eugenia polyantha, Apium graveolens, and Nigella sativa are extracts which in preclinical trial can reduce uric acid serum, increase urinary uric acid excretion. Allopurinol is an inhibitor of the xanthine oxidase enzyme which can also reduce the increase of hsCRP in subjetcs with hyperuricemia. Methods This study was a double blind randomized controlled trial (RCT). The subjects were hyperuricemic patients aged $\geq 18$ years. The subject was divided into groups that received $3000 \mathrm{mg} /$ day of herbal extracts and allopurinol $100 \mathrm{mg} /$ day for 4 weeks. Evaluation of serum uric acid and urinary uric acid urine were every week, and hsCRP levels was baseline and end of intervention. Other parameters related to the safety of use were examined every 2 weeks. Results A number of 44 hyperucemia subjects, 23 subjects received herbal extracts and 21 subjects received allopurinol. The decrease of uric acid serum levels in the herbal extract group was $0,467 \pm 1,123 ; 0,600 ;-2,70-3,00(\mathrm{p}=0.027)$, while in the allopurinol group $1,114 \pm 0,813 ; 1,30 ;-1,30-2,30(p=0,000)$. Uric acid excretion in the herbal extract group decrease $71,00 \pm 1,970 ; 5,50 ;-92,00-702,00(\mathrm{p}=0,269)$ and in the allopurinol group decrease $64,54 \pm 1,298 ; 22,00 ;-29,00-440,0 \quad(p=0.003)$. The reduction of hsCRP in the herbal extract group was $0.08 \pm 0.639$; $0.01 ;-1.55-2.05(\mathrm{p}=0.658)$, and the allopurinol group was $-0.33 \pm$ $0.806 ;-0.01 ;-2.73-0.31 \quad(p=0.256)$. Conclusion Herbal extracts (Eugenia poliantha, Apium graveolens and Nigella sativa) and allopurinol can reduce serum uric acid levels in patients with hyperuricemia. Allopurinol also can reduce urinary uric acid excretion.
\end{abstract}

\section{Introduction}

Hyperuricemia is a condition in which serum uric acid levels increase $\geq 7 \mathrm{mg} / \mathrm{dl}$ in men and $\geq 6 \mathrm{mg} /$ $\mathrm{dl}$ in women. It is a risk factor for the onset of arthritis gout, gout or kidney stone nephropathy and the incidence of cardiovascular disease. ${ }^{1}$ The prevalence of hyperuricemia as reported in Bali in 2010 about
$14.5 \% .^{2}$ Allopurinol as a widely used as xanthine oxidase inhibitor has reported side effects 5-10\%. ${ }^{3}$

Eugenia polyantha, Apium graveolen, and Nigella sativa are uric acid lowering extracts that have become standardized herbal medicines in Indonesia. In preclinical studies, the composition of 
herbal extracts that are effetive at reducing serum uric acid levels is at a dose of $30-40 \mathrm{mg}$. At a dose of $30 \mathrm{mg}$ it consists of $13 \mathrm{mg}$ (43.3\%) bay leaf extract (Eugenia polyantha), $10 \mathrm{mg}(33.3 \%)$ celery extract (Apium graveolens) and $7 \mathrm{mg}(23,33 \%)$ black cumin seed extract (Nigella sativa). ${ }^{4}$ Eugenia polyantha contains $0.2 \%$ essential oils, flavonoids (quercetin, quercitrin, myricitrin and myricetin) and tannins. ${ }^{5}$ Quercitrin and myricetin are the competitive inhibitors of the xanthine oxidase enzyme. ${ }^{6}$ The main content of Apium graveolen is flavonoids apigenin, inositol, asparagine, glutamine, choline and linamarosa. ${ }^{5}$ Flavonoids apigenin is a xanthine oxidase competitive inhibitor enzyme. Infuse $10 \%$ of Apium graveolen $(5 \mathrm{ml} / \mathrm{kg}$ ) can reduce uric acid levels as same as probenecid $20 \mathrm{mg} / \mathrm{kg}$ and associated with increased uric acid excretion. Nigella sativa (black cumin) has been shown to increase urine volume and excretion of uric acid in urine in pre-clinical studies. 8,9

$$
\text { Eugenia polyantha (43.3\%), Apium }
$$

graveolen (33.3\%) and Nigella sativa $(23.33 \%)$ at doses of $2000 \mathrm{mg} / 24$ hours have been shown to reduce serum uric acid levels by $0,12 \pm 0.91 \mathrm{mg} / \mathrm{dl}$ (p $<0.05$ ) and increase urinary excretion of uric acid $1.78 \pm 390.83 \mathrm{mg} / 24$ hours $(\mathrm{p}<0.05)$ at day $14^{\text {th. }} 10$

$$
\text { C-reactive protein (CRP) is mostly }
$$
synthesized in the liver. In the transcription phase is affected by proinflammatory cytokines. IL- 6 being the main regulator supported by $\mathrm{C} / \mathrm{EBP} \beta$ and $\mathrm{C} / \mathrm{EBP} \gamma$ is a key factor of transcription. In addition, IL-6 will provide a signal strengthened by IL- $1 \beta$ and TNFa in enhancing the transcription process of CRP.11 Increased expression of CRP in conditions of uric acid levels $>6 \mathrm{mg} / \mathrm{dl}$ is caused by activation of p38 and ERK44/42 MAPK. ${ }^{12}$ The inflammatory process that occurs is caused by accumulation of monosodium urate (MSU) crystals caused by increasing serum uric acid levels. Monosodium urate binds to caspase I activating NALP3 inflammasone, resulting in the expression of IL-1 $\beta$ and IL-18.13 In another study it was also mentioned that MSU induces the release of
TNF cytokines. Evidence in other studies also states that hyperuricemia is associated with hsCRP levels. 14

The purpose of this study was to determine the effect of herbal extracts (Eugenia polyantha, Apium graveolens and Nigella sativa) on serum uric acid, uric acid and high sensitivity c-reactive protein levels in patients with hyperuricemia and the safety of herbal extracts compared with allopurinol.

\section{Methods}

This study is a double blind randomized controlled trial. Subjects were hyperuricemic patients with inclusion criteria aged $>18$ years with blood uric acid levels $>7 \mathrm{mg} / \mathrm{dl}$ (male) and $>6 \mathrm{mg} / \mathrm{dl}$ (female) and willing to take drugs given with exclusion criteria for liver function disorders with AST $>40 \mathrm{U} / \mathrm{L}$; and or ALT $>65 \mathrm{U} / \mathrm{L}$; impaired kidney function with creatinine $>1.5 \mathrm{mg} / \mathrm{dl}$ or ureum $>40 \mathrm{mg} / \mathrm{dl}$; malignancy; use of drugs that affect uric acid levels such as diuretics, pyrazinamides, and salicylic acid; chronic inflammation (RA, IBD); attacks of acute gout; hypersensitivity to allopurinol and use of antiinflammatory drugs: NSAIDs, steroids and colchicine for the hsCRP variable.

Screening is done to get prospective subjects who meet the inclusion criteria. Subjects who had used gout-lowering drugs, washed out 2 weeks before screening. The samples were randomly divided into 2 groups, group $\mathrm{X}$ was the group that received herbal extracts $3 \times 2$ capsules (@500mg) in a day for 28 days, group $\mathrm{Y}$ was the group that received allopurinol $3 \times 2$ capsules $(100 \mathrm{mg}$ ) in a day for 28 days. Both groups received nutritional education according to the nutrition guide for patients with hyperuricemia from the nutrition department of Kariadi Hospital.

On day 0 , day 7 , day 14 , day 21 and day 28 , samples were taken for examination of serum uric acid, urinary uric acid and history and physical examination related to complaint taking the drugs given. On day 0,14 and 28, a routine blood test was carried out: hemoglobin, leukocytes, platelets, 
ureum, creatinine, AST, and ALT. Serum hsCRP levels were taken at day 0 and day 28. Data obtained were recorded in the subject's developmental record.

\section{Results}

Based on the randomization of subjects divided into two groups, 23 subjects received herbal extracts therapy with a dose of $3 \times 1000 \mathrm{mg}$ and 21 people received allopurinol therapy with a dose of $1 \mathrm{x}$ $100 \mathrm{mg}$ allopurinol. The flowchart of the selection of research subjects is presented in Figure $\mathbf{1}$ below. Serial analysis (Friedman's test) in both groups showed that there was a significant (significant) decrease in serum uric acid levels 0 to 4 weeks, both in the herbal extracts group $(\mathrm{p}=0.026)$ and allopurinol group ( $\mathrm{p}=0.000)$ (Figure 2). The median value for the allopurinol group was lower than herbal extracts starting from the $1^{\text {st }}$ week to the $4^{\text {th }}$ week. In Figure 3 above shows that serial analysis of uric acid excretion in urine in the allopurinol group, there was a significant decrease between week 0 and week 4 (Friedman test, p $=0.003$ ), whereas in the herbal extracts group there was no significant difference (Friedman test, $\mathrm{p}=0.269$ ). The median uric acid level of the second week in the herbal extracts group was greater than in the allopurinol group, although statistically the difference was not significant $(\mathrm{p}>$ 0.05). HsCRP levels in both groups did not differ either at week $0(p=0.379)$, week $4(p=0.267)$, and decrease levels of hsCRP at week 4 from week 0 (p = 0.295). In both groups, there was a decrease in HsCRP level 4 weeks from week 0 (P herbal extract $=$ 0.658 and $\mathrm{p}$ allopurinol $=0.256$ ). However, the hsCRP level of the herbal extract group tended to decrease at 4 weeks $(0.08 \pm 0.639 ; 0.01 ;-1.55-2.05)$ and the allopurinol group tended to increase at the 4th week $(-0.33 \pm 0.806 ;-0.01 ;-2,73-0,31)$. 


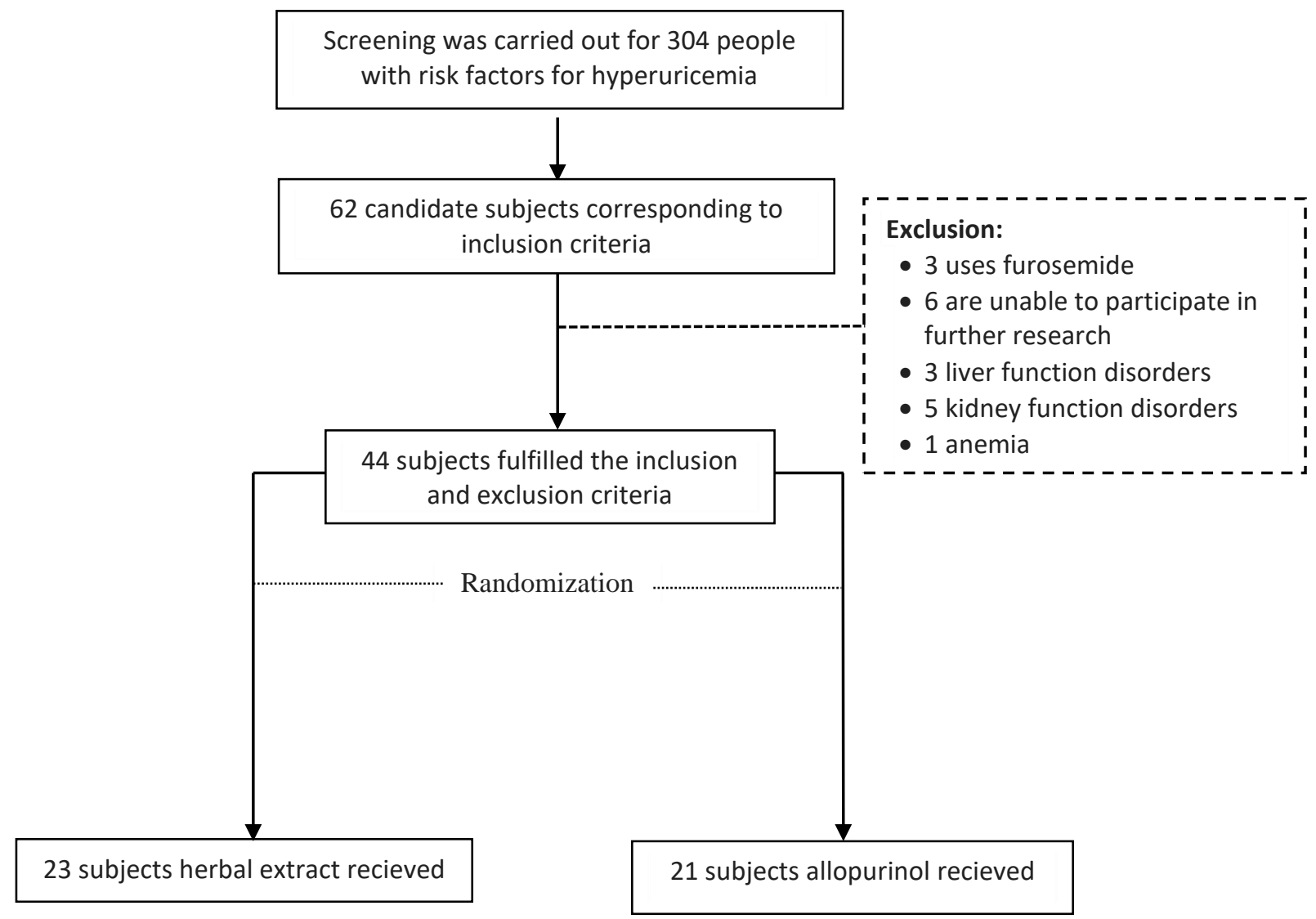

Figure 1. Subjects Disposition

Table 1. Baseline characteristics of Randomized Subjects

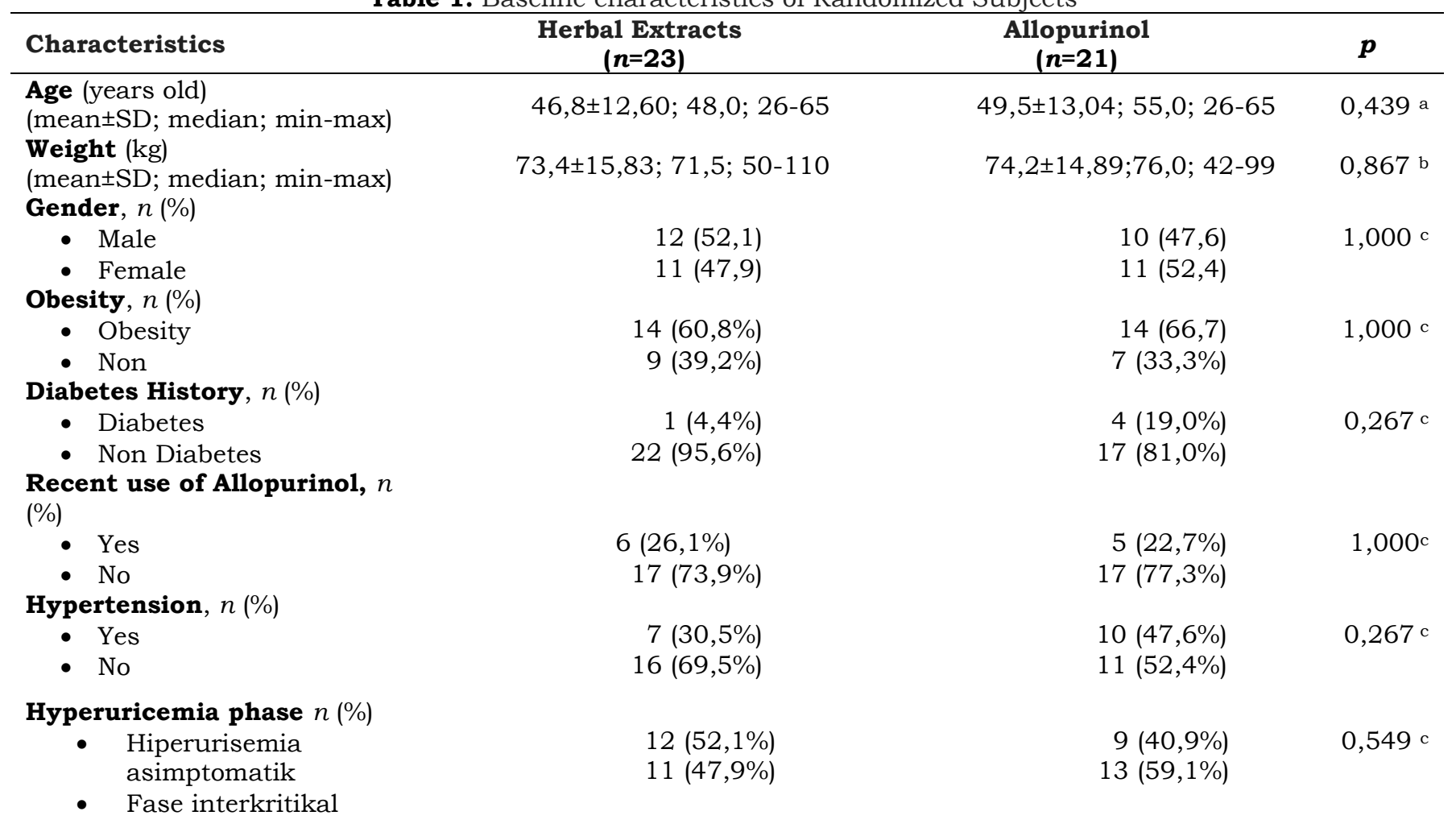


Serum uric acid levels

(mg/dl)

(mean \pm SD; median; min-max)

Urinary uric acid levels

(mg/dl)

(mean \pm SD; median; min-max)

HsCRP leves (mg/dl)

(mean \pm SD; median; min-max)
$7,59 \pm 1,253 ; 7,25 ; 6,1-11,7$

$7,45 \pm 1,022 ; 7,40 ; 6,1-9,9$

$0,864^{a}$

$121,71 \pm 1,906 ; 60,50 ; 5,0-724,0$

$115,50 \pm 1,304 ; 65,10 ; 15,0-515,0$

$0,211^{\mathrm{a}}$

$0,63 \pm 0,62 ; 0,46 ; 0,08-2,38$

$0,379 a$

Table 2. Comparison of Serum Uric Acid Levels in Both Treatment Groups

\begin{tabular}{lcrc}
\hline & $\begin{array}{c}\text { Herbal Extracts } \\
\text { (n=23) }\end{array}$ & $\begin{array}{c}\text { Allopurinol } \\
\text { (n=21) }\end{array}$ & $\boldsymbol{p}$ \\
\hline Week 0 & $7,59 \pm 1,253 ; 7,25 ; 6,1-11,7$ & $7,45 \pm 1,022 ; 7,40 ; 6,1-9,9$ & $0,864^{\mathrm{a}}$ \\
Week 1 & $7,51 \pm 1,358 ; 7,05 ; 6,0-10,5$ & $6,79 \pm 1,878 ; 6,50 ; 4,4-11,1$ & $0,080^{\mathrm{a}}$ \\
Week 2 & $7,75 \pm 1,258 ; 6,90 ; 5,7-10,4$ & $6,60 \pm 1,578 ; 6,60 ; 4,3-10,4$ & $0,078^{\mathrm{a}}$ \\
Week 3 & $7,28 \pm 1,464 ; 6,90 ; 3,9-10,5$ & $6,33 \pm 1,444 ; 6,10 ; 3,9-10,1$ & $0,040^{\mathrm{b}}$ \\
Week 4 & $7,13 \pm 1,313 ; 6,95 ; 4,7-10,5$ & $6,33 \pm 1,580 ; 6,20 ; 4,0-11,2$ & $0,016^{\mathrm{a}}$ \\
\hline
\end{tabular}

a Mann-Whitney test b $T$-independent test

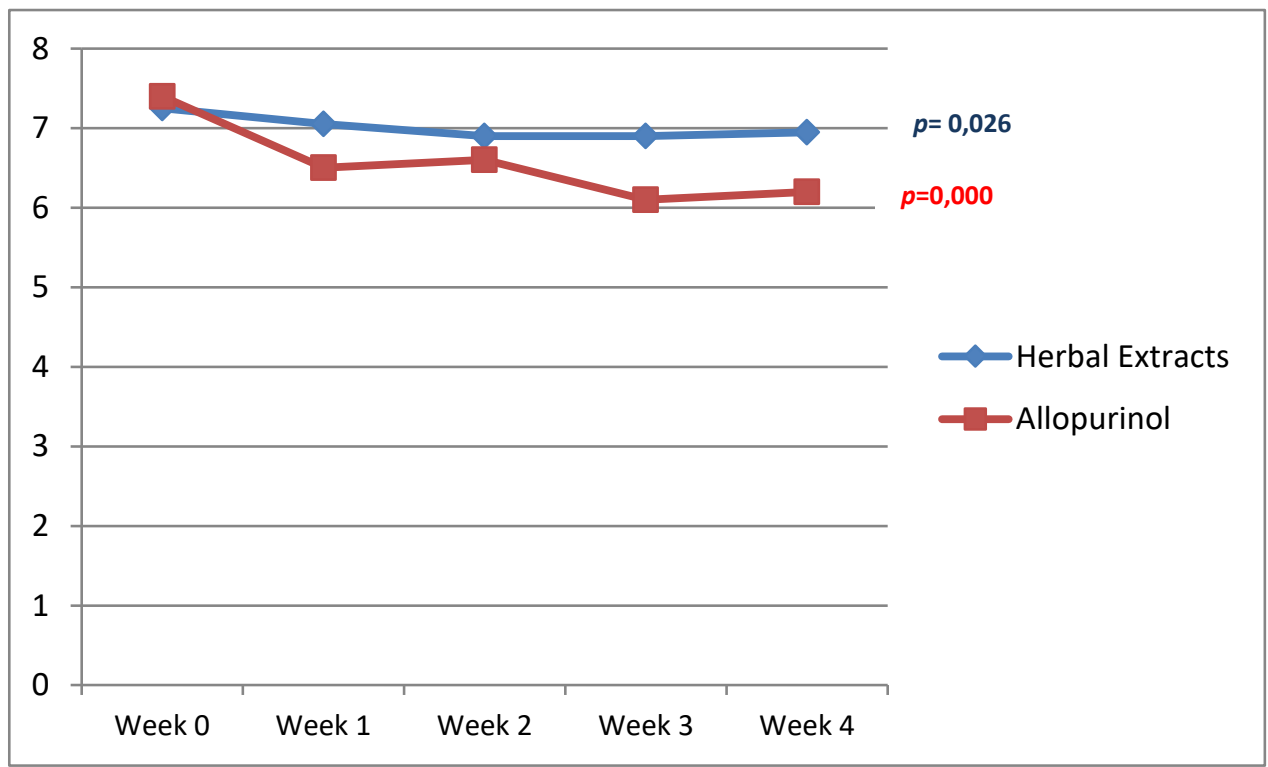

Figure 2. Graphic of Serum Uric Acid Levels in Both Treatment Groups

Table 3. Comparison of Decreased Serum Uric Acid Level in Both Treatment Groups

\begin{tabular}{lrrr}
\hline & $\begin{array}{c}\text { Herbal Extracts } \\
(\mathbf{n = 2 3 )}\end{array}$ & $\begin{array}{c}\text { Allopurinol } \\
(\mathbf{n = 2 1 )}\end{array}$ & $p$ \\
\hline Week 0 and 1 & $0,075 \pm 0,786 ; 0,10 ;-2,75-1,40$ & $0,6619 \pm 1,253 ; 0,90 ;-3,10-2,00$ & $0,007^{\mathrm{a}}$ \\
Week 0 and 2 & $0,316 \pm 1,220 ; 0,25 ;-2,2-4,1$ & $0,847 \pm 0,888 ; 1,00 ;-0,70-2,30$ & $0,032^{\mathrm{a}}$ \\
Week 0 and 3 & $0,333 \pm 1,142 ; 0,40 ;-2,70-2,70$ & $1,114 \pm 0,824 ; 1,142 ;-0,70-2,40$ & $0,013^{\mathrm{b}}$ \\
Week 0 and 4 & $0,467 \pm 1,123 ; 0,600 ;-2,70-3,00$ & $1,114 \pm 0,813 ; 1,30 ;-1,30-2,30$ & $0,018^{\mathrm{a}}$ \\
\hline
\end{tabular}

aMann-Whitney test b T-independent test 
Table 5. Comparison of urinary uric acid levels at week 0 to week 4 of the both treatment groups

\begin{tabular}{|c|c|c|c|}
\hline & \multicolumn{2}{|c|}{ Group } & \multirow[t]{2}{*}{$\mathrm{p}$} \\
\hline & $\begin{array}{c}\text { Herbal Extracts } \\
(\mathbf{n = 2 3 )}\end{array}$ & $\begin{array}{l}\text { Herbal Extracts } \\
(\mathbf{n = 2 3 )}\end{array}$ & \\
\hline Week 0 & $121,71 \pm 1,906 ; 60,50 ; 5,0-724,0$ & $115,50 \pm 1,304 ; 65,10 ; 15,0-515,0$ & $0,211^{a}$ \\
\hline Week 1 & $71,08 \pm 92,273 ; 52,50 ; 5,0-481,0$ & $54,50 \pm 36,129 ; 54,0 ; 7,0-168,0$ & $0,750^{a}$ \\
\hline Week 2 & $59,93 \pm 30,591 ; 75,00 ; 13,0-108,0$ & $57,76 \pm 30,990 ; 58,0 ; 6,0-125,0$ & 0,577 a \\
\hline Week 3 & $58,10 \pm 32.109 ; 49,50 ; 14,0-113,0$ & $50,28 \pm 29,094 ; 52,00 ; 7,0-147,0$ & $0,426^{a}$ \\
\hline Week 4 & $50,708 \pm 31,170 ; 50,0 ; 10,0-117,0$ & $50,95 \pm 18,540 ; 53,0 ; 11,0-79,0$ & $0,975^{b}$ \\
\hline
\end{tabular}

aMann-Whitney test b T-independent test

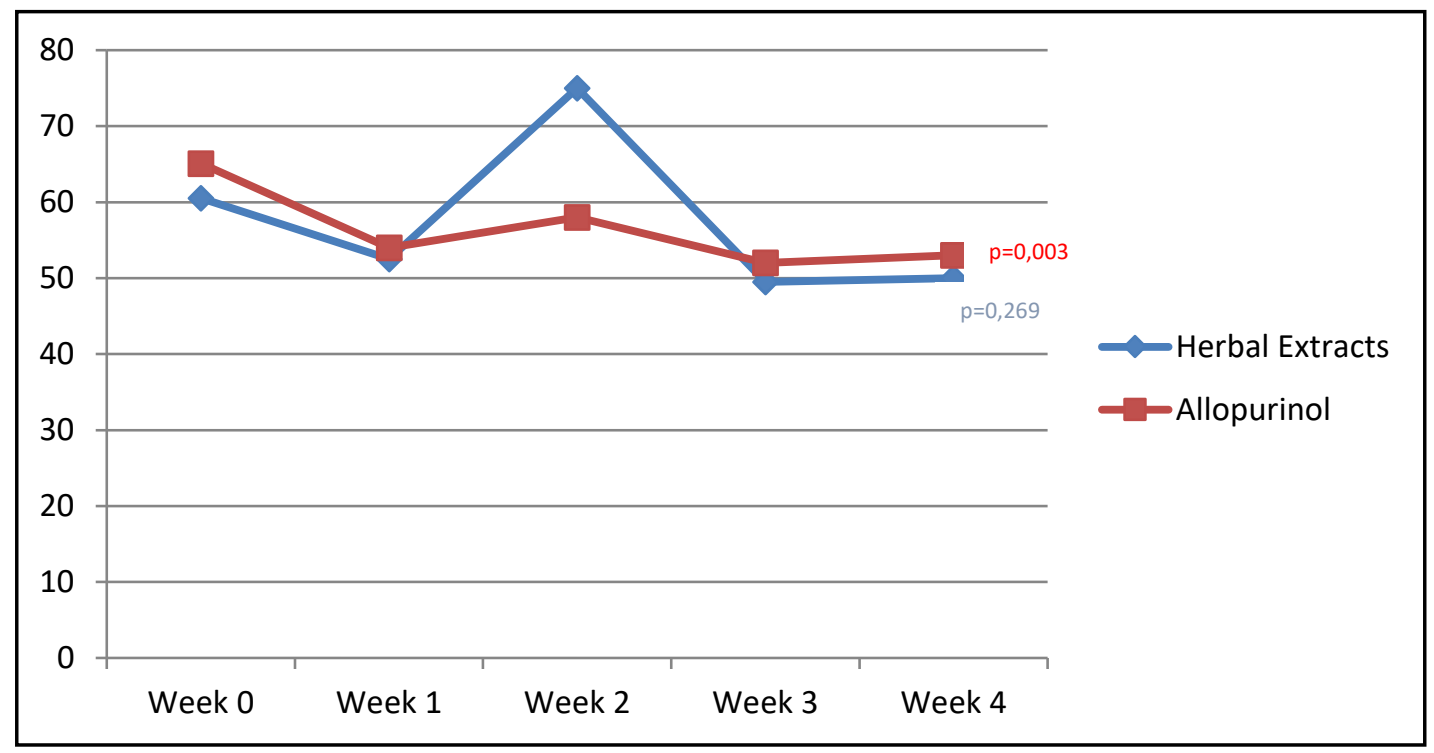

Figure 3. Graphic of Urinary Uric Acid Excretion Levels in Both Treatment Groups

Table 6. Comparison of decrease urinary Uric Acid levels of both treatment groups

\begin{tabular}{lrrr}
\hline & $\begin{array}{c}\text { Herbal Extracts } \\
(\mathbf{n = 2 3 )}\end{array}$ & \multicolumn{1}{c}{$\begin{array}{c}\text { Allopurinol } \\
(\mathbf{n = 2 1 )}\end{array}$} & $p$ \\
\hline Week 0 and 1 & $50,62 \pm 2,092 ; 9,0 ;-407,9-644,0$ & $60,99 \pm 1,299 ; 22,00 ;-44,00-454$ & 0,127 \\
Week 0 and 2 & $61,77 \pm 1,923 ;-4,65 ;-54,00-690,00$ & $57,73 \pm 1,280 ; 19,00 ;-38,00-439,00$ & 0,142 \\
Week 0 and 3 & $63,61 \pm 1,827 ; 0,85 ;-77,00-623,00$ & $65,21 \pm 1,295 ; 32,00 ;-83,00-455,00$ & 0,054 \\
Week 0 and 4 & $71,00 \pm 1,970 ; 5,50 ;-92,00-702,00$ & $64,54 \pm 1,298 ; 22,00 ;-29,00-440,0$ & 0,183 \\
\hline
\end{tabular}


Table 7. Comparison of HsCRP levels at week 0 and week 4 of Both Treatment Groups

\begin{tabular}{|c|c|c|c|}
\hline & $\begin{array}{c}\text { Herbal Extracts } \\
(n=23)\end{array}$ & $\begin{array}{l}\text { Allopurinol } \\
(n=21)\end{array}$ & $\boldsymbol{P}$ \\
\hline Week 0 & $0,63 \pm 0,62 ; 0,46 ; 0,08-2,38$ & $0,39 \pm 0,31 ; 0,30 ; 0,01-3,00$ & $0,379 a$ \\
\hline Week 4 & $0,55 \pm 0,917 ; 0,70 ;-1,55-2,050$ & $0,73 \pm 0,860 ; 1,40 ; 0,04-3,00$ & $0,267 a$ \\
\hline $\begin{array}{l}\text { Decreases levels week } 0 \\
\text { and } 4\end{array}$ & $0,08 \pm 0,639 ; 0,01 ;-1,55-2,05$ & $-0,33 \pm 0,806 ;-0,01 ;-2,73-0,31$ & $0,295^{a}$ \\
\hline P Week 4th and $0^{\text {th }}$ & $0,658^{b}$ & $0,256^{b}$ & \\
\hline
\end{tabular}

a Mann-Whitney test b Wilcoxon test

\section{Discussion}

Administration of allopurinol $100 \mathrm{mg} / 24$ hours for 4 weeks found a decrease in serum uric acid levels 1.29 $\pm 0.629 \mathrm{mg} / \mathrm{dl}$, when compared to the study conducted by Scott et al.(1966) obtained a mean decrease in uric acid levels from 9.3 to $5.8 \mathrm{mg} / \mathrm{dl}$ at the same dose as 2 weeks. ${ }^{15}$ In another study with 120 days of allopurinol with a mean dose of $261 \mathrm{mg} /$ day it was found to decrease as much as $34 \%$ (from 10 to $6.6 \mathrm{mg} / \mathrm{dl}$ ) . ${ }^{16}$

In the group that received herbal extracts there was a decrease from day 0 to day 28 (week 4) with $0.47 \pm$ 1.123, although compared to the group of allopurinol smaller (1.11 \pm 0.813$)$, but the decreased serum uric acid levels with a dose of $3000 \mathrm{mg} /$ day is greater than dose of $2000 \mathrm{mg} /$ day $(0.12 \pm 0.91) .{ }^{4}$

The Phase III febuxostat study comparing the effectiveness of febuxostat $80 \mathrm{mg} /$ day, $120 \mathrm{mg} /$ day, and $240 \mathrm{mg} /$ day with allopurinol $300 \mathrm{mg} /$ day for 28 weeks with the output of normal serum uric acid levels $1<6$ $\mathrm{mg} / \mathrm{dl})$ was 76\% (122/161), 87\% (163/188), and 94\% $(78 / 83)$, while allopurinol 41\% $(85 / 208) .{ }^{17}$ In this study the reduction in serum uric acid levels reached target $13 \%$ $(3 / 23)$ for herbal exctract group and 33\% (7/21) for allopurinol group (100 mg/day).

The excretion of uric acid in this study was seen that the two groups did not difference. If compared to uric acid excretion at week 0 and week 4, allopurinol decreased uric acid excretion significantly $(\mathrm{p}=0.037)$ with a decrease in uric acid level of urine $24.3 \pm 44.11 \mathrm{mg} / \mathrm{dl}$. Previous studies (doses of $2000 \mathrm{mg} /$ day) found a significant increase in the second week (from week 1 (114.11 \pm 745.74 $\mathrm{mg} /$ day), but after 4 weeks there were no significant differences. ${ }^{4}$

In another study in patients with hyperuricemia who received allopurinol $300 \mathrm{mg}$ for 6 months, there was a decrease in excretion of uric acid levels as much as $36.4 \%$, but decreased slightly when compared with febuxostat $80 \mathrm{mg}$ for 6 months which decreased by $58,6 \%$ .18

Apium graveolens has uricosuric and diuretic effect. In this study there was no examination of 24-hour urine and only using randomized urine, so diuretic effect of Apium graveolens cannot be evaluated, and the synergistic diuretic and uricosuric effects can be considered as reasons for not increasing uric acid levels in the herbal extract treatment group, as well as the effect of xantin oxidase inhibitors that can reduce overproduction of serum uric acid .

Changes in hsCRP levels at week 4 and week 0 in the two groups showed no significant difference, but the herbal extract treatment group experienced a decrease in hsCRP level week 4 from week $0(0.08 \pm 0.639 \mathrm{mg} / \mathrm{dl})$ compared the allopurinol group increased $(0.33 \pm 0.806$ $\mathrm{mg} / \mathrm{dl})$.

A study with subject obese postmenopausal women $(\mathrm{BMI}>30 \mathrm{~kg} / \mathrm{m} 2)$ received a calorie retention diet and Nigella sativa oil 3 grams/day for 8 weeks. Decrease in hsCRP level in the group that received Nigella sativa oil more than the group that only received a calorie retention diet $(-54.5 \%$ compared to $-21.4 \%$, with $\mathrm{p}=0.01) .19$

The administration of allopurinol in patients with hyperuricemia with type II DM has been reported to have the effect of reducing hsCRP levels. Allopurinol at a dose of $300 \mathrm{mg}$ for 3 years has been shown to reduce hsCRP levels when compared with the control group $(0.16$ $\pm 0.07 \mathrm{mg} / \mathrm{dl}$ and $0.35 \pm 0.18$, with $\mathrm{p}<0.001)^{20}$

Allopurinol in patients with hyperuricemia associated endothelial function with hsCRP as a marker is 
as done by Kanbay et.al (2011). The subjects of this study were hyperuricemia patients who were treated with allopurinol $300 \mathrm{mg} /$ day for 16 weeks compared to placebo and subjects with normal uric acid levels. In patients with hyperuricemia who received therapy there was a greater decrease in hsCRP $(7.4 \pm 5.8 \mathrm{mg} / \mathrm{dl}$ to $4.6 \pm 3.7 \mathrm{mg} / \mathrm{dl}, \mathrm{p}$ $=0.003)$ compared with placebo $(6.9 \pm 3.4 \mathrm{mg} / \mathrm{dl}$ to $5.9 \pm$ $3.8 \mathrm{mg} / \mathrm{dl}, \mathrm{p}=0.04)$, but it has not been as low as hsCRP level in patients who do not have hyperuricemia $(3.4 \pm 2.2$ $\mathrm{mg} / \mathrm{dl}) \cdot 21$

Some of the studies above were carried out with a duration of 8 weeks of intervention on the use of Nigella sativa with a dose of (human) use of 3000 $\mathrm{mg} /$ day. Allopurinol in the above study was intervened for a minimum of 16 weeks at a dose of $300 \mathrm{mg} /$ day.

\section{Research Limitations}

Some limitations of this study include: intervention duration of 4 weeks, examination of uric acid excretion is measured using random urine, lipid profiles (HDL, LDL and triglycerides) were not examined and no assessment of glycemic status in patients with type II DM.

\section{Acknowledgment}

We would like to thank to PT Djamu DJAGO-Semarang for producing NEURAT ${ }^{\circledR}$ as standardized herbal medicine to reduce serum uric acid level, Badan Pengkajian dan Penerapan Teknologi (BPPT) for its collaboration in getting sponsorship from the Ministry of Research, Technology and Higher Education of the Republic of Indonesia.

\section{REFERENCES}

1. Putra T. Hiperurisemia. In: Sudoyo E a., editor. Buku Ajar Ilmu Penyakit Dalam. VI. Jakarta: Interna Publishing; 2014. p. 3180-5.

2. Kambayana, Putra R. Hyperurcemia and Factors Relating in the Community of Balinese Population: An Epidemiological survey. in press. 2010.

3. Terketaub R. The management of gout and hyperuicemia. In: Hochberg MC, Silman AJ, Smolen JS, Weinblatt ME, Weisman MH, editors.
Rheumatology. 5th ed. Philadelphia: Mosby Elsivier; 2011. p. 1841-65.

4. Wibowo AE, Agustini K, Ningsih S. Uji Farmakologi Formula (Syzigium polianthum, Avium graveolens dan Nigella sativa). Jakarta; 2008.

5. Sudibyo M. Alam Sumber Kesehatan : Manfaat dan Kegunaan. Jakarta: Balai Pustaka; 1998.

6. Lin J. Molecular modeling of flavonoids that inhibits xanthine oxidase. 2002;294:167-72.

7. Winata F. Pengaruh Infus Daun Seledri Terhadap Kadar Asam Urat Darah Kera. Universitas Widya Mandala, Jakarta; 1988.

8. Zaoui A, Cherrah Y, Dubois MAL, Settaf A, Amarouch H, Hassar M. Diuretic and hypotensive effects of Nigella sativa on the spontaneously hypertensive rat. Therapie. 2000;55(3):379-82.

9. Tekeoglu I, Dogan A, Demiralp L. Effects of Thymoquinone ( Volatile Oil of Black Cumin ) on Rheumatoid Arthritis in Rat Models. PhytotherRes. 2006;20(May):869-71.

10. Hadi S, Sudarsono, Suntoko B, Azzaki A, Henry S. Uji klinik formula ekstrak herbal (Eugenia polyantha, Apium graveolens, Nigela sativa) Pada Penderita Hiperurisemia. Universitas Diponegoro; 2008.

11. Salazar J, Martínez MS, Chávez-castillo M, Núñez V, Añez R, Torres Y, et al. C-Reactive Protein : An In-Depth Look into Structure , Function, and Regulation. 2014;2014.

12. Billiet L, Doaty S, Katz JD, Velasquez MT. Review of Hyperuricemia as New Marker for Metabolic Syndrome. ISRN Rheumatol [Internet]. 2014;2014:1-7.

13. Busso N, So A. Mechanisms of inflammation in gout. Arthritis Res Ther. 2010;12(2):1090-6.

14. Yang T, Ding X, Wang Y lun, Zeng C, Wei J, Li H, et al. Association between high-sensitivity Creactive protein and hyperuricemia. Rheumatol Int. 2016;36(4):561-6.

15. Scott JT, Hali AP, Grahame R. Allopurinol in Treatment of Gout. Br Med J. 1966;2(5509):3217. 
16. Delbarre F, Amor B, Auscher C, de Gery A.

Treatment of gout with allopurinol. A study of 106 cases. Ann Rheum Dis [Internet]. 1966;25:627-

33.

17. Schumacher HR, Becker MA, Wortmann RL, Donald PAMAC, Hunt B, Streit J, et al. Effects of Febuxostat Versus Allopurinol and Placebo in Reducing Serum Urate in Subjects With Hyperuricemia and Gout: A 28-Week, Phase III, Randomized, Double-Blind, Parallel-Group Trial. 2008;59(11):1540-8.

18. Goldfarb DS, MacDonald PA, Gunawardhana L, Chefo S, McLean L. Randomized controlled trial of febuxostat versus allopurinol or placebo in individuals with higher urinary uric acid excretion and calcium stones. Clin J Am Soc Nephrol.

2013;8(11):1960-7.

19. Mahdavi R, Namazi N, Alizadeh M, Farajnia S.

Nigella sativa oil with a calorie-restricted diet can improve biomarkers of systemic inflammation in obese women: a randomized double-blind, placebo-controlled clinical trial. J Clin Lipidol [Internet]. 2016

20. Liu P, Wang H, Zhang F, Chen Y, Wang D, Wang Y. The Effects of Allopurinol on the Carotid Intima-media Thickness in Patients with Type 2

Diabetes and Asymptomatic Hyperuricemia: A Three-year Randomized Parallel-controlled Study. Intern Med. 2015;54(17):2129-37.

21. Kanbay M, Huddam B, Azak A, Solak Y, Kadioglu GK, Kirbas I, et al. A Randomized Study of Allopurinol on Endothelial Function and Estimated Glomular Filtration Rate in Asymptomatic Hyperuricemic Subjects with Normal. 2011;1887-94. 